Information Management and Business Review

Vol. 5, No. 7, pp. 347-359, July 2013 (ISSN 2220-3796)

\title{
Impact of Perceptual Dimensions and Behavioral dimension on brand equity in Pakistan
}

\author{
*Javeria Shabbir ${ }^{1}$, Kashif Ur Rehman ${ }^{2}$ \\ ${ }^{1}$ Shaheed Zulfikar Ali Bhutto Institute of Science \& Technology (SZABIST), Islamabad, Pakistan \\ 2Iqra University, Islamabad, Pakistan \\ *dr.msjaveria@gmail.com
}

\begin{abstract}
The purpose of this study is to investigate the effects of consumer-based brand equity dimensions on Pakistani mobile branded market. To do this, data were collected through convenient sampling from 250 consumers of mobile users from Universities and shopping malls. Islamabad and Rawalpindi were selected for data collection. Through self-administered questionnaire based surveys in order to investigate the mobile's brand as product. The analysis involved Regression and Mean values that, all alternative hypotheses have been accepted. The regression analysis results show all dimensions positively and significantly, influences brand equity. This research study is important in identifying the sources of brand equity in Pakistan's mobile industry. This is the first study investigating the perceptual and behavioral dimension of consumer-based brand equity of mobile brand in Pakistan. Hence, it makes a contribution for both marketer and practitioners for devising strategies.
\end{abstract}

Keywords: Brand equity, brand loyalty, perceived quality, brand awareness, brand association and mobiles

\section{Introduction}

Building strong brands has become a marketing priority for many organizations today because it yields a number of advantages. Strong brands help the firm establish an identity in the marketplace (Aaker, 1991). According to Kim \& Damhorst, (2010) the prominent marketing strategies include creating value for consumers. The equity of a brand is the result of consumers' perception of it. Brand equity actually represents a product position in the minds of consumers in the marketplace. It is precisely the well-established representation and meaningfulness of the brand in the minds of consumers that provides equity for the brand name. In markets, we see an array of products on the shelf while visiting markets. Some brand names are alien to us while others we recognize due to advertising or other reasons. Today brands come and vanish. Launching new brands is becoming a hit or miss match. Still marketers are approaching with the new ones due to the hope for successful brands and its immense profits. There are other benefits as "Brands reduce consumer research search cost, perceived risk and signal quality of the product" (Cass \& Grace, 2003). According to Roy \& Chau (2011) brands are increasing in day by day due to global similarity in taste and mindset of consumers. Because of many reasons, brands have become so important to the consumers and retailers that, during a nine year period from the mid 1980s and well into 1990s, over 1000 studies related to brands and branding were conducted from around the world (Jungmi, Susan \& Fiorito, 2002). In measuring the overall value of a brand, marketing researchers and practitioners has begun to examine the concept of "brand equity" (Keller, 1993). Brand equity has an enormous spectrum and "can be discussed from the perspective of the manufacturer, retailer, or the consumer" (Eda et al, 2005).

Brand equity have two types to measure overall brand equity, first is financial-based brand equity and other is consumer-based brand equity (Keller 1993). Since consumer-based brand equity occurs when the consumer is familiar with the brand and holds some strong, unique and favorable association in memory (Keller, 1993). Aaker (1991) states, there are two key sources of consumer-based brand equity dimensions that are perceptual and behavioral. Whereas the perceived quality, brand awareness and brand association are the function of consumer cognitive processes. Brand loyalty falls in the behavioral category as it is a function of consumer's behavior. Companies are realizing that brand equity is one of their most valuable intangible assets. Keller in (1993) studied the concept Consumer-Based Brand Equity (CBBE). Then Aaker (1991) defines brand equity as multidimensional concept that consists of perceived quality, brand loyalty, brand awareness, brand associations and other proprietary assets. Many international brands are facing 
intense competitive pressure as they are entering new market internationally. The new markets and different consumer taste, preferences and resulting decisions demand for complex decisions and comprehensive strategies to compete well. It becomes important for brand managers to gain understanding of their customer's preferences in term of their brands. Brand managers of mobile phone need to understand how value is created in their industry. This research will help those managers of their customer's preferences and will identify how value is created for the firm in Pakistani branded mobile market so firms can establish effective strategies and gain competitive advantage. The findings from this study will verify impact of dimensions of consumer based brand equity of Pakistani consumers. Furthermore, it will help marketers and practitioners to build strong brand equity strategies regarding Pakistani consumers for mobile phone.

Purpose of the Study: The major purpose of this research paper is three fold: First, to examine the dependency of consumer-based brand equity dimensions on overall brand equity in mobile phones, Second, to examine the interrelationship/association between four consumer-based brand equity dimensions in same industry, and Third, to analyze the tendency of Pakistani consumer's attitude towards brand equity and its dimensions.

Research Question: The research questions addressed in this study are:

Question no.1: Is there a significant relationship between consumer-based brand equity and overall brand equity?

Question no.2: Is there an association between four consumer-based brand equity dimensions?

\section{Literature Review}

Brands can be discussed from two perspectives. A brand refers to "A distinguishing name and /or symbol (such as a logo, trade mark or package design) intended to identify the goods or services of a seller or group of sellers, and to differentiate their goods from those of the competitors" (Aaker, 1991) and "brand is a notion in the minds of the consumers" (Kapferer, 2004). Aaker definition refers to attributes relating to the branded products and goods and refers the branding concept as the outcome of cognitive processes in the mind of consumers. Keller (1993) also stresses on brand knowledge and image and describes brand as notions and associations in the mind of the consumer. This goes towards a more intangible meaning of the brands while the definition which is provided by Aaker (1991) points towards both tangible and intangible image of the brand incorporating logo and symbols which are tangible parts of the brands and value concept which is intangible part of the brand. Branding is the complete package, which generates brand equity for the products and services.

It is an accumulation or a set of different beliefs about the branded product or service. A belief about the brand that can add value to the consumer image could be a way to establish superiority. Communicates social status or thinking, superior quality and consumer's higher taste sometimes without even experiencing the actual product. This belief can also be transferred to a new brand by the same brand or further extensions. These all add ups to build brand equity of the brand. The broad meaning of brand equity is similar to the conceptual definition provided by Farquhar (1989), who states that brand equity is the value generated by a product or service by branding. Yoo \& Donthu (2001) who tested and operationalized the model of brand equity based their studies on this concept. Aaker (1991) stated that the brand equity measurement and examination of brand equity is essential because it indicates the health of brand and its impact in effective brand management. To know your customer is essential in providing value to your target market. Without proper and timely knowledge, it is a time wasting drill to devise strategies for brand. In addition, by providing value to customers, brand equity indirectly enhances value to the firm (Baldauf, Cravens \& Binder, 2003). The most commonly cited definition and conceptualization of brand equity is provided by Aaker (1991). As cited by (Tong, 2006) in her dissertation, Aaker (1991) defines it as a set of assets (and liabilities) linked to a brand's name and symbol that add to (or subtract from) the value provided by a product or service to a firm and/or that firm's customers. According to Aaker brand equity is a multidimensional construct and its dimensions are five i.e. brand loyalty, perceived quality brand awareness, brand associations and other propitiatory assets. Mostly in empirical research, the fifth dimension of consumer based brand equity is ignored because it deals with the firm internal mechanisms and here in this research we are emphasizing 
with consumer perception. These are also not directly related to consumers such as distribution or patents of a certain brand (Gil, Andre's \& Salinas, 2007).

\section{Dimension of Brand Equity}

\section{Perceptual Dimension}

Brand awareness: Brand awareness refers to "the ability of a potential buyer to recognize or recall that a brand is a member of a certain product category" (Aaker, 1991). Brand awareness is an important antecedent of brand equity. It is the first step in selecting a brand as consumers will only select a brand if they are aware of its existence furthermore Radder \& Huang (2008) in their paper explained it as a vital component for the brand to be included in the consideration set of consumers. According to Keller (1993) brand awareness could be described as brand node in the memory of the consumers i.e. how quickly the brand name comes to the mind of the consumer. There are two components of brand awareness that are recognition and recall. However, they may seem similar but there is difference in these two concepts. Recognition is when consumers recognize a brand because it was previously seen or heard by them however, Recall happen, when consumers are provided with a special cue only then they is able to retrieve the brand (Ross \& Harradine, 2004). Some authors have defined brand awareness with only recognition such as Rossiter and Percy (1997) and some have incorporated both components such as Keller, (1993). Tong, (2006) in her dissertation used different scales of brand awareness and brand association similarly in this research we are using different scales for the concepts. We in our research identify Brand awareness as a perceptual dimension of brand equity. Brand awareness is the 'perception' of a consumer related to the brand not a behavioral dimension like brand loyalty.

In this context, "Earlier models - such as Aaker's brand equity model and Keller's customer-based brand equity model - have focused heavily on how consumer perceive and evaluate brands by investigating certain knowledge structures such as brand awareness, image and personality"(Esch, Langner, Schmitt, and Geus, 2006). Many researchers have examined brand awareness in brand equity context. According to Gil, Andre \& Salinas, (2007), Aaker (1991) suggested that brand equity might be generated by awareness in four ways. It creates a brand node in the memory of the consumer so consumer is exposed to the brand and familiarity occurs. He states that it develops trust and adds the brand in the consumer's consideration set. Wilcox, Laverie, Kolyesnikova, Duhan \& Dodd (2008), examined the effect of perceived quality and brand awareness on brand survival and concluded that to maintain brand equity these two facets of brand equity play an important role. According to Marber, Wellen, Yoon, and Torres (2008) establishing enhancing and maintain brand image and awareness are main goals of brand management. Assessing its importance, both academically and for practitioners, it is important to understand how Pakistani consumers react to ward brand-building strategies.

Brand associations: One of the dimensions of brand equity is brand associations. It is vital as, "consumer's brand associations are a key element in brand equity formation and management" (Río, Vázquez \& Iglesias, 2001), Brand association is considered one of the many sources of brand equity so to better manage the brand equity it is crucial to understand this concept. Aaker (1997) defined brand associations as, "the set of human characteristics associated with a brand" (Aaker, 1997). Keller (1993) defined brand associations as the other informational nodes linked to the brand node in memory and contained the meaning of the brand for consumers. According to Keller (1998), Brand associations could be product related or non-product related. Arthur Cheng-Hsui Chen (2001) and Aaker (1991) categorized brand associations into 11 types: product attributes; intangibles; customer benefits; relative price; use/application; user/customer; celebrity/person; Life-style/personality; product class; competitors; and country/geographic area. Keller (1993) takes the consumer based brand strength (brand loyalty) approach and keller's (1993) brand equity model was based on Aaker underlying framework of brand equity. Keller (1993) states that brand equity is a condition in which a consumer developed strong unique and favorable brand associations to the brand and has familiarity with the brand. These associations are recalled when buying. Due to information overload it is becoming very difficult to through the message to the target market. Renowned researcher Aaker (1991) stated that branded products have personalities and consumers purchase these brands due to the images 
they associate with those brands. For example "the 'sexy' toothpaste versus the 'practical' toothpaste verses the toothpaste for fathers who love their children" (Baran \& Blask, 1984). It is critical for any marketer to position his branded products or services in such a way that associations he wants to develop in the mind of the consumers aligns with the positioning with the target market. A successful strategy will develop strong and positive desired associations for the brand commending profitable business and brand equity.

Perceived Quality: Quality plays an important part when consumers are deciding to buy any branded product or service. Quality is a very important product attribute, which makes the criterion for selecting any branded product, or service thus is very crucial for the consumer's decision-making process. There are two types of quality i.e. Product quality and perceived quality. Perceived quality is defined as the "a consumer's judgment about a product's overall excellence or superiority" (Zeithaml, 1988). Objective quality could be measured in a technical sense. From the definitions it becomes clear that the perceived quality is subjective phenomenon and product quality is objective in nature. Perceived quality is more product performance related while perceived quality is a function of consumer cognitive processes. Wilcox, Laverie, Kolyesnikova, Duhan, \& Dodd, (2008), examined the effect of perceived quality and brand awareness on brand survival and concluded that to maintain brand equity these two facets of brand equity play an important role. Perceived quality is also researched in services sector. Hame (2006), studies the relationship of consumer expectations with perceived service quality. According to Pappu, Quester, \& Cooksey (2005) perceived quality generates satisfied consumers who in turn increases awareness and brand loyalty of the consumers, helps retain the customers and increase the chances of acceptance of brand extensions (Story \& Loroz, 2005), studies the effect of technology, perceived quality on brand extensions and how the brand equity plays its part in brand extension successes. It is equally important to know how this dimension affects consumers of Pakistani market.

\section{Behavioral Dimension}

Brand loyalty: Brand loyalty is the one important dimension of brand equity (Tong, 2006). Previous researchers have proved its strong role as source of brand equity because "brand loyalty is a standard component of many brand-choice models" (Shum, 2004). According to Atilgan et al, (2005) the antecedent which has the highest effect on brand equity is brand loyalty which means that it is the strongest source of achieving brand equity. Due to its critical role in brand equity formation, mostly emphasis is on maintaining brand loyalty (Schoenbachler, Gordon \& Aurand, 2004). Due to the complex nature of the construct there are many definitions. The best definition which gives a composite view of the construct and most cited is provided by Jacoby (1971) which states that Brand loyalty is "the biased (non-random) behavioral response (purchase) expressed over time by some decision-making unit with respect to one or more alternative brands out of a set of brands and is a function of psychological processes" (Rundle \& Bennett, 2001). According to Uncles \& Dowling, (1998), generally brand loyalty could be defined as attitude of the consumers toward branded products or services. Consumers exhibit loyalty for different product categories for examples some women are particularly brand loyal to some cosmetic categories or towards some stores or activities like mostly men in Pakistan are brand loyal to cricket in sports category. Evans, Moutinho \& Raaij (1996) stated four types of brand loyal consumer: hard- core loyal consumers, brand switchers, new users and non-users. Hard core brand loyal consumers are those consumers who are very loyal to the brand and will not accept any other substitute for the brand while brand switchers are those who have many brand in their 'consideration set' and they are loyal to different brands in different product categories and they choose from them whenever shopping. Then there are non-users who "tend not to be loyal to any brand and as for new users, they are not familiar to any brand at all" (Lau, Chang, Moon \& Liu, 2005).

Conceptual Framework: This framework is built upon the conceptual framework for brand equity presented by Yoo, Donthu and Lee (2000). They adopted this concept from Aaker 1991 model of brand equity. In this model, brand awareness, brand association, perceived quality and brand loyalty are treated as the independent variables and brand equity as dependent variable. 
Figure 1: Consumer-Based Brand Equity Model

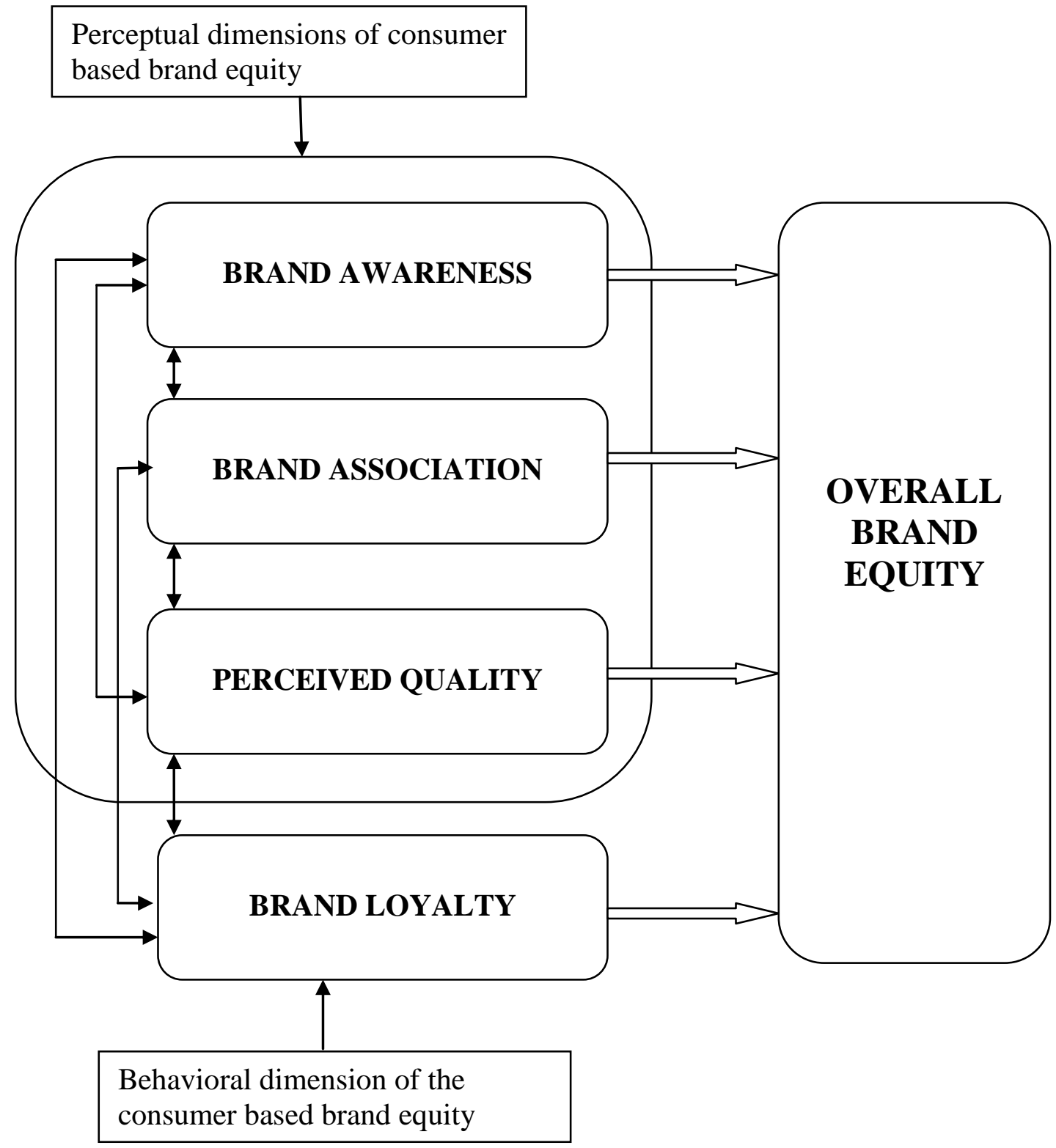

Hypothesis Development

H1:

Ho: There is no significant relationship between brand awareness and brand equity.

Ha: There is significant relationship between brand awareness and brand equity.

H2:

Ho: There is no significant relationship between brand association and brand equity.

Ha: There is significant relationship between brand association and brand equity.

H3:

Ho: There is no strong relationship between brand loyalty and brand equity.

Ha: There is strong relationship between brand loyalty and brand equity.

H4:

Ho: There is no significant relationship between perceived quality and brand equity. 
Ha: There is significant relationship between perceived quality and brand equity.

H5:

Ho: There is no positive association between brand awareness and brand association.

Ha: There is positive association between brand awareness and brand association.

H6:

Ho: There is no positive association between brand awareness and brand loyalty.

Ha: There is positive association between brand awareness and brand loyalty.

H7:

Ho: There is no positive association between brand awareness and perceived quality.

Ha: There is positive association between brand awareness and perceived quality.

H8:

Ho: There is no positive association between brand association and brand loyalty.

Ha: There is positive association between brand association and brand loyalty.

H9:

Ho: There is no positive association between brand association and perceived quality.

Ha: There is positive association between brand association and perceived quality.

H10:

Ho: There is no positive association between brand loyalty and perceived quality.

Ha: There is positive association between brand loyalty and perceived quality.

\section{Methodology}

Data Collection: The data was conducted through survey research method. The data used to test the research hypotheses were gathered within two metropolitan cities (Rawalpindi and Islamabad) of Pakistan through a structured questionnaire. The questionnaire was distributed to the sample of 250 consumers (male and females) from universities, community and markets. A total of 250 questionnaires were distributed and 215 questionnaires were returned, self-administered survey for a response rate $84 \%$ approximately. After eliminating all incomplete questionnaires, 210 were used for result and analysis. The data was collected through survey based research method using structured questionnaire. The questionnaire included 22 numbers of items and responses to these items were measured using seven point Likert scale from "Strongly Disagree" (1) to "Strongly Agree" (7). First of all this questionnaire was consisted of two parts having five basic variables, i.e. Brand awareness, Brand association, Perceived quality, Brand loyalty and Brand equity and last part was consisted of demographic profiles i.e. Gender, Age, current mobile phone and duration of using that mobile. All measures in the questionnaire are adopted from previous work.

The dimensions of brand equity are measured according to the work by Yoo and Donthu (2001), further extended by Gil, Andre's \& Salinas, (2007). The reason to choose these scales was that they have been derived from Yoo \& Donthu (2001), whereas their model of brand equity was selected as the core model of this research study. Another reason to choose the measures that their research studies "brought both academics and practitioners closer to a universally accepted measure of brand equity" (Eda, Şafak \& Serkan, 2005). The data were analyzed in accordance with data driven quantitative approach. A total of 4 items represents Brand equity, 3 items for brand awareness, 4 items for brand association, 3 items for perceived quality, 4 items for brand loyalty and 4 items representing demographic profiles etc. The data were obtained by closed-ended survey questionnaire adopted from previous research studies.

Hypothesis Testing: In hypothesis testing, Regression analysis, correlation, descriptive analysis and mean values were used. The first four hypotheses were investigated to find out the relationship between CBBE Dimensions and Brand Equity. The remaining six hypotheses were investigated to find out the association within four dimensions of brand equity.

\section{Results and Analysis}

By using SPSS 13.0 windows, the reliability of the scales was evaluated by calculating as Cronbach's Alpha for all variables was 0.90 . 
H1, It was hypothesized that there was a significant relationship between brand awareness (as independent variable) and brand equity (i.e. dependent variable). Linear Regression analysis supported this hypothesis. So Ho was rejected. R square value showed that brand equity depends on brand awareness. The model resulted in an $\mathrm{R}^{2}$ of 0.311 , accounting for 31 percent of the variance in brand equity. This showed that approximately $31 \%$ brand equity was dependent on brand awareness and has positive relation with each other. If there is $100 \%$ brand equity, then $31 \%$ contribution is from brand awareness. Those consumers who are more aware about mobile brand are more inclined to build positive perceptions about the brand and thus brand equity is created.

Model Summary

\begin{tabular}{lllll}
\hline Model & R & R Square & Adjusted R Square & Std. Error of the Estimate \\
\hline 1 & $.558(\mathrm{a})$ & .311 & .307 & 1.01801 \\
\hline
\end{tabular}

\begin{tabular}{llllllll}
\multicolumn{2}{l}{ Coefficients (a) } & & & & \\
Model & & $\begin{array}{l}\text { Unstandardized } \\
\text { Coefficients }\end{array}$ & & \multicolumn{2}{l}{$\begin{array}{l}\text { Standardized } \\
\text { Coefficients }\end{array}$} & t & Sig. \\
\hline & & & & B & Std. Error & Beta & \\
1 & (Constant) & 2.116 & .286 & & 7.407 & .000 & \\
& Total aware & .557 & .058 & .558 & 9.685 & & .000 \\
\hline
\end{tabular}

a Dependent Variable: totalequi

According to these results, data is significant at 0.05 level and Beta value also shows that if there is any change in brand equity then $55 \%$ change is because of awareness of brand. Finally, brand awareness is first stage towards building of consumer brand equity.

H2, It was hypothesized that there was a significant relationship between brand association (as independent variable) and brand equity (i.e. dependent variable). Linear Regression analysis supported this hypothesis. $R$ square value showed that brand equity depends on brand association. The model resulted in an $\mathrm{R}^{2}$ of 0.311 , accounting for 31 percent of the variance in brand equity. Thus, the data supported the second alternative hypothesis. So Ho was rejected. This showed that approximately $31 \%$ brand equity was depend on brand association and has positive relation with each other. If there is $100 \%$ brand equity, then $31 \%$ contribution is from brand association. Those consumers who have positive association toward mobile brand are more inclined to draw strong brand equity.

\section{Model Summary}

\begin{tabular}{lllll}
\hline Model & $\mathbf{R}$ & R Square & Adjusted R Square & Std. Error of the Estimate \\
\hline 1 & $.555(\mathrm{a})$ & .309 & .305 & 1.01968 \\
\hline
\end{tabular}

a Predictors: (Constant), totalasso

Coefficients(a)

\begin{tabular}{lllllll}
\hline Model & $\begin{array}{l}\text { Unstandardized } \\
\text { Coefficients }\end{array}$ & $\begin{array}{l}\text { Standardized } \\
\text { Coefficients }\end{array}$ & t & & Sig. \\
\hline & & & B & Std. Error & Beta \\
$1 \quad$ (Constant) & 2.079 & .291 & & 7.150 & & .000 \\
& Totalasso & .566 & .059 & .555 & 9.634 & .000 \\
\hline
\end{tabular}

a Dependent Variable: totalequi

According to these results, data is significant at 0.05 level and Beta value also shows that if there is any change in brand equity, so $55 \%$ change is because of positive association with mobile brand.

H3, It was hypothesized that there was a significant relationship between perceived quality (as independent variable) and brand equity (i.e. dependent variable). Linear Regression analysis supported this hypothesis $\mathrm{R}$ square value showed that brand equity depends on perception about brand quality. The model resulted in an $\mathrm{R}^{2}$ of 0.52 , accounting for 52 percent of the variance in brand equity. 
Model Summary

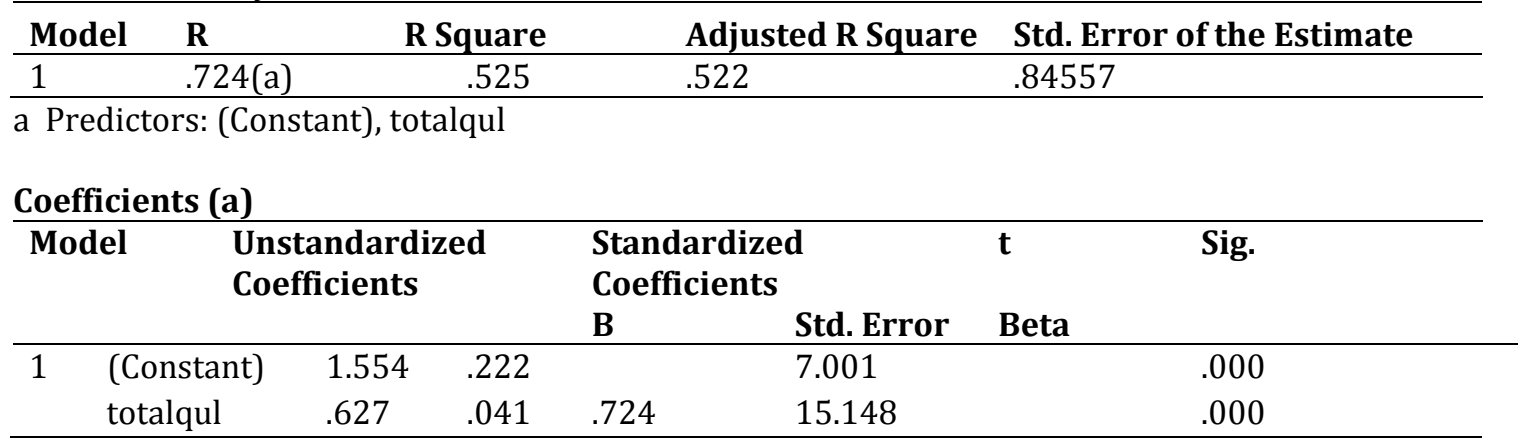

a Dependent Variable: totalequi

Thus, the data supported the third alternative hypothesis. So Ho was rejected. This showed that approximately $0.52 \%$ brand equity was dependent on perceived quality and has strong relation with each other. If $100 \%$ brand equity exists, then $52 \%$ contribution is from perception about quality of brand. Those consumers who perceived more quality about mobile brand are more inclined to draw strong brand equity. According to these results, $t$ value showed that data is significant at 0.05 level and Beta value also shows that if there is any change in brand equity, then $72 \%$ change is because of perceived quality toward brand. Finally, perception about quality of brand is significant towards building of strong brand equity.

H4, It was hypothesized that there was a significant relationship between brand loyalty (as independent variable) and brand equity (i.e. dependent variable). Linear Regression analysis supported this hypothesis. $R$ square value showed that brand equity depends on brand loyalty. The model resulted in an $\mathrm{R}^{2}$ of 0.525 , accounting for 52 percent of the variance in brand equity.

Thus, the data supported the forth alternative hypothesis. So Ho was rejected. This showed that approximately $52 \%$ brand equity was depend on brand loyalty and has strong relation with each other. If there is $100 \%$ brand equity, then $52 \%$ contribution is from brand loyalty. Those consumers who are more loyal toward mobile brands are more likely to develop strong brand equity. This is in line with the previous results in western culture. It proves that by enhancing brand loyal behavior in consumer overall brand equity is increased.

Model Summary

\begin{tabular}{lllll}
\hline Model & R & R Square & Adjusted R Square & Std. Error of the Estimate \\
\hline 1 & $.725(a)$ & .525 & .523 & .84518 \\
\hline
\end{tabular}

Coefficients (a)

\begin{tabular}{lccllll} 
Model & \multicolumn{2}{l}{ Unstandardized } & \multicolumn{2}{l}{$\begin{array}{l}\text { Standardized } \\
\text { Coefficients }\end{array}$} & & \multicolumn{2}{l}{ Coefficients } & t & Sig. \\
& & & B & Std. Error & Beta & \\
\hline $1 \quad \begin{array}{l}\text { (Constant) } \\
\text { totaloyal }\end{array}$ & 1.326 & .236 & & 5.610 & & .000 \\
\hline
\end{tabular}

According to these results, data is significant at 0.05 level and Beta value also shows that if there is any change in brand equity, then $72 \%$ change is because of loyalty of mobile brand. Finally, brand loyal is most critical element for building strong brand equity.

H5, It was hypothesized that there is a positive association between brand awareness and brand association. Correlation analysis supported this hypothesis. Result showed that $\mathrm{R}=0.669$ it showed the positive relationship between brand awareness and brand association. When consumers are more familiar about brand, then there is more chance to form an association about mobile brand. Thus, the data supported the fifth alternative hypothesis. So Ho was rejected. 


\begin{tabular}{|c|c|c|c|}
\hline & & totalaware & Totalasso \\
\hline \multirow[t]{3}{*}{ Totalaware } & Pearson Correlation & 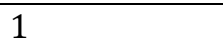 & $.669\left(^{* *}\right)$ \\
\hline & Sig. (2-tailed) & & .000 \\
\hline & $\mathrm{N}$ & 210 & 210 \\
\hline \multirow[t]{3}{*}{ Totalasso } & Pearson Correlation & $.669(* *)$ & 1 \\
\hline & Sig. (2-tailed) & .000 & \\
\hline & $\mathrm{N}$ & 210 & 210 \\
\hline
\end{tabular}

** Correlation is significant at the 0.01 level (2-tailed).

H6, It was hypothesized that there was a positive relation between brand awareness and brand loyalty. Correlation analysis supported this hypothesis. Result showed that $\mathrm{R}=0.50$, it showed the positive relationship between brand awareness and brand loyalty. When consumers are more familiar with the brand , then the possibility to purchase that certain brand increases and can also enhance brand loyalty. Repeated exposure makes easier for the consumer to recall the brand when buying and instead of choosing a new one they repurchase again and thus become loyal toward brand. The data supported the sixth alternative hypothesis. So Ho was rejected.

Correlations analysis (brand awareness and perceived quality)

\begin{tabular}{llll}
\hline & & totalaware & totalqul \\
\hline Totalaware & Pearson Correlation & 1 & $.642\left(^{* *}\right)$ \\
& Sig. (2-tailed) & & .000 \\
& $\mathrm{~N}$ & 210 & 210 \\
Totalqul & Pearson Correlation & $.642\left(^{* *}\right)$ & 1 \\
& Sig. (2-tailed) & .000 & \\
& $\mathrm{~N}$ & 210 & 210 \\
\hline
\end{tabular}

** Correlation is significant at the 0.01 level (2-tailed).

Correlations analysis (brand awareness and brand loyalty)

\begin{tabular}{lllc}
\hline \multicolumn{1}{c}{ totalaware } & Totaloyal \\
\hline Totalaware & Pearson Correlation & 1 & $.503\left(^{* *}\right)$ \\
& Sig. (2-tailed) & & .000 \\
\multirow{5}{*}{ Totaloyal } & $\mathrm{N}$ & 210 & 210 \\
& Pearson Correlation & $.503\left(^{* *}\right)$ & 1 \\
& Sig. (2-tailed) & .000 & \\
& $\mathrm{~N}$ & 210 & 210 \\
\hline
\end{tabular}

** Correlation is significant at the 0.01 level (2-tailed).

H7, It was hypothesized that there was a positive relation between brand awareness and perceived quality. Correlation analysis supported this hypothesis. Result showed that $\mathrm{R}=0.64$, it showed the strong association between brand awareness and perceived quality. Familiarity to a brand, creates about perceived quality of mobile brand. When consumers are positively brand aware then perceived quality of the consumer will be positive and vice versa. Exposure to the brand also creates a feeling of the brand presence and they relate this to higher quality. Thus, the data supported the seventh alternative hypothesis. So Ho was rejected.

H8, It was hypothesized that there was a positive relation between brand association and brand loyalty. Correlation analysis supported this hypothesis. Result showed that $\mathrm{R}=0.57$, it showed the strong and significant relationship between brand association and brand loyalty. When consumers have positive association towards mobile brand, then they are more liable to become brand loyal. Thus, the data supported the eight alternative hypotheses. So Ho was rejected. 
Correlations analysis (brand association and brand loyalty)

\begin{tabular}{llll}
\hline & & totalasso & totaloyal \\
\hline Totalasso & Pearson Correlation & 1 & $.570\left(^{* *}\right)$ \\
& Sig. (2-tailed) & & .000 \\
& $\mathrm{~N}$ & 210 & 210 \\
Totaloyal & Pearson Correlation & $.570\left(^{* *}\right)$ & 1 \\
& Sig. (2-tailed) & .000 & \\
& $\mathrm{~N}$ & 210 & 210 \\
\hline
\end{tabular}

** Correlation is significant at the 0.01 level (2-tailed).

H9, It was hypothesized that there was a positive relation between brand association and perceived quality. Correlation analysis supported this hypothesis. Result showed that $\mathrm{R}=0.58$, it showed the strong and significant relationship between brand association and brand loyalty. From this research it is confirmed that when consumers have positive association towards brand, then they are more likely to have high perceived quality. Brand managers can devise strategies in their communication campaign, which creates associations of a brand to higher quality. Branded mobile consumers can be attracted to buy the mobile brands by building positive associations in their minds, which attract them. The data supported the ninth alternative hypotheses. So Ho was rejected.

Correlations analysis (perceived quality and brand association)

\begin{tabular}{lllc}
\hline & \multicolumn{1}{c}{ totalqul } & totalasso \\
\hline totalqul & Pearson Correlation & 1 & $.581\left(^{* *}\right)$ \\
& Sig. (2-tailed) & & .000 \\
& $\mathrm{~N}$ & 210 & 210 \\
\multirow{5}{*}{ totalasso } & Pearson Correlation & $.581\left(^{* *}\right)$ & 1 \\
& Sig. (2-tailed) & .000 & \\
& $\mathrm{~N}$ & 210 & 210 \\
\hline
\end{tabular}

** Correlation is significant at the 0.01 level (2-tailed).

H10, It was hypothesized that there was a positive relation between perceived quality and brand loyalty. Correlation analysis supported this hypothesis. Result showed that $\mathrm{R}=0.668$, it showed the strong and significant relationship between perceived quality and brand loyalty. When consumers have high perceived quality, then they are more liable to become brand loyal. The data supported the tenth alternative hypotheses. So Ho was rejected.

Correlations analysis (perceived quality and brand loyalty)

\begin{tabular}{llll}
\hline & & Total & totalqul \\
\hline totaloyal & Pearson Correlation & 1 & $.668\left(^{* *}\right)$ \\
& Sig. (2-tailed) & & .000 \\
& $\mathrm{~N}$ & 210 & 210 \\
totalqul & Pearson Correlation & $.668\left(^{* *}\right)$ & 1 \\
& Sig. (2-tailed) & .000 & \\
& $\mathrm{~N}$ & 210 & 210 \\
\hline
\end{tabular}

** Correlation is significant at the 0.01 level (2-tailed).

\section{Conclusion and Implications}

It is found that the consumer based brand equity of mobile brands does exist in Pakistani branded mobile market. Consumers are impacted by all four dimensions of consumer based brand equity. According to research question 1, Finding of this research identifies brand loyalty and perceived quality of the brand as the most important effecting variable in brand equity formation in Pakistani mobile markets. Both of the 
dimensions have an equal affect on consumer choice. This finding is in line with previous research regarding brand loyalty while perceived quality is identified equally important to the first time in this study and thus a new finding. This finding is not in line with the previous research where mainly brand loyalty was identified as the most important antecedent of brand equity. Previous research was done in western culture and theses research results show consumer behavior related to eastern culture, specifically of Pakistani branded mobile consumers. The results of this research study show that for Pakistani branded mobile consumer's quality is very important variable and enhances the brand equity of the mobile brands. To attract customers and keep existing ones brand managers must enhance quality of their brands. Previous empirical research identifies brand loyalty as the strongest antecedent of brand equity (Eda, Şafak, Serkan, 2005). This is confirmed with our results as our results show the significant relationships between other dimensions of brand loyalty as well as its direct effect on brand loyalty.

Our study proves the existence of brand loyal consumers in Pakistani mobile brand users. Thus this it could be inferred that by enhancing brand loyalty of Pakistani branded mobile consumers higher brand equity could be achieved. The second strongest antecedent of brand equity, which has impact on consumers brand equity, is Perceived quality. This current research confirms it is an important dimension. Yasin, Noor \& Mohamad (2007) stated that due to brand equity high perceived quality could give marketers the power to demand premium prices. Same is also generalizable in Pakistani mobile brand market. Enhanced perceived quality will enhance the consumer based brand equity of branded mobile consumers and they will be willing to pay higher prices for their preferred brands. The effect of brand awareness on brand equity formation is also analyzed brand awareness of the consumers is found to effect positively and significantly in our study it is confirmed that this dimension of brand equity does effect the brand equity of the Pakistani consumer. According to Yasin, Noor \& Mohamad, (2007) different brand associations may affect how consumers perceive that brand's identity and may associate with that brand and due to strong and unique brand equity is formed in the minds of consumers. This is also confirmed by our research in Pakistan mobile brand scenario. The results showed that showed that the consumers brand associations have relationship with other dimensions of the brand equity model. This confirms it is an important dimension in Aaker model and this model also generalizable in Pakistani market.

Implications: Brand equity creates value to customer by enhancing customers: Brand equity can affect customer's confidence in purchasing decision due to familiarity or past use experience with mobile brands. Both perceived quality and brand association can enhance mobile user's satisfaction with use experience. Brand equity measurement can enhance programs to attract new customers and retain old ones. Brand awareness, brand association and perceived quality provide reasons to buy and affect use satisfaction. After these types of research studies, strong brand equity allows brand extensions, higher margins by permitting premium pricing and reduced promotions.

\section{Suggestions}

- Marketers should enhance mobile brand consumers brand loyalty to increases brand equity of their products.

- Producers of mobiles should not underestimate the value of other dimensions, as they are main part in brand loyalty formation, which enhances brand equity.

- They should focus on high quality and should focus their strategies to maintain relationships with their loyal customers through loyalty programs or augmented features of products.

- Quality and loyalty dimensions should be the main focus of brand managers to cultivate brand equity in Pakistani consumers.

\section{Suggestions for Future Research}

- Other product categories should be examined as cosmetics and apparel

- Services sector should be examined

- Other antecedents of brand equity like marketing mix should and non marketing mix nature should be examined.

- Other contemporary concepts like brand evangelism and brand love should be researched in this scenario. 


\section{References}

Aaker, D. A. (1991). Managing Brand Equity, The Free Press, New York, NY.

Aaker, D. A. (1992). Managing the most important asset: Brand Equity. Planning Review, 20(5) 56-8.

Aaker, J. L. (1997). Dimensions of brand personality. Journal of Marketing Research, 36(3), 345-55.

Arthur, C. C. (2001). Using free association to examine the relationship between the characteristics of brand associations and brand equity. Journal of Product \& Brand Management, 10(7), 439-451.

Baldauf, A., Cravens, S. K. \& Binder, G. (2003) Performance consequences of brand equity management: Evidence from organizations in the value chain. Journal of Product \& Brand Management, 12 (4) 220236.

Cass O. A. \& Grace, D. (2003). An Exploratory Perspective Of Service Brand Associations. Journal Of Services Marketing, 17 (5), 452-475.

Eda, A., Şafak, A. \& Serkan, A. (2005). Determinants of The Brand Equity: A Verification Approach In The Beverage Industry In Turkey. Marketing Intelligence And Planning, 23(3) 237-248.

Esch, F. R., Langnr, T. \& Schmitt, H. B. (2006). Are brands forever? How brand knowledge and relationships affect current and future purchases. Journal of Product \& Brand Management, 15(2) 98-105.

Evans, M., Moutinho, L. \& Raaij, W. F. V. (1996). Applied consumer Behavior, Addison- Wesley Pub. Co., Harlow; Reading, Mass.

Farquhar, P. H. (1989). Managing brand equity. Marketing Research, 1 24-33.

Gil, B. R., Andre's, F. E. \& Salinas, M. E. (2007). Family as a source of consumer-based brand equity. Journal of Product \& Brand Management, 16(3), 188-199.

Hamer, O. L. (2006), Confirmation Perspective On Perceived Service Quality. Journal of Services Marketing, 20(4), 219-232.

Jacoby, J. (1971). A model of multi-brand loyalty. Journal of Advertising Research, 2, 25-31.

Jungmi, O., Susan, S. \& Fiorito, L. (2002). Korean women's clothing brand loyalty. Journal of Fashion Marketing and Management, 6(3), 206-222.

Kapferer, J. N. (2004). The New Strategic Brand Management: Creating and Sustaining Brand Equity Long Term, Kogan Page, London, .

Keller, K. L. (1993). Conceptualizing, measuring, and managing customer-based brand equity. Journal of Marketing, 57, 1-22.

Keller, K. L. (1998). Strategic Brand Management. Building, Measuring and Managing Brand Equity, Prentice Hall, Englewood Cliffs, NJ., .

Kim B. H., Kim, G. W. \& Jeong, A. A. (2003). The effect of consumer-based brand equity on firms' financial performance. Journal of Consumer Marketing, 20 (4), 335-351.

Kim, J. \& Damhorst, M. L. (2010). Effects of Level of Internet Retailer's Service Quality on Perceived Apparel Quality, Perceived Service Quality, Perceived Value, Satisfaction, and Behavioral Intentions Toward an Internet Retailer. Clothing \& Textiles Research Journal, 28, 56-73.

Lau, M. M., Chang, M. T., Moon K. L. \& Liu, W. S. (2005). Brand loyalty of sportswear in Hong Kong. Journal of textile and apparel technology and apparel, 5(1).

Marber, A., Wellen, M. P., Yoon, B. S. \& Torres, B. (2008). We Are Going To Shop Till We Drop The Japanese resurgence for designer and high fashion goods - a case study. Competitiveness Review: An International Business Journal, 18(3) 217-226

Pappu, R., Quester, G. P. \& Cooksey, W. R. (2005). Consumer-based brand equity: Improving the measurement. Journal of Product \& Brand Management, 14(3), 143-154

Radder, L. \& Huang, W. (2008). High-involvement and low-involvement products :A comparison of brand awareness among students at a South African university. Journal of Fashion Marketing and Management, 12(2), 232-243.

Río, D. B. A., Vázquez, R. \& Iglesias, V. (2001). The effects of brand Associations On Consumer Response. Journal Of Consumer Marketing, 18(5), 410-425.

Ross, J. \& Harradine, R. (2004). I am not wearing that! Branding and young children. Journal of Fashion Marketing and Management, 8, 11-26.

Rossiter, J. R. \& Percy, L. (1987). Advertising and Promotion Management, McGraw-Hill, New York, NY.

Roy, R. \& Chau, R. (2011). Consumer based brand equity and status-seeking motivation for a global versus local brand. Asia Pacific Journal of Marketing and Logistics, 23, 270-284. 
Rundle, T. S. \& Bennett, B. (2001). A brand for all seasons? A discussion of brand loyalty approaches and their applicability for different markets. Journal of Product \& Brand Management, 10(1), 25-37.

Schoenbachler, D. D., Gordon, L. G. \& Aurand, T. W. (2004). Building brand loyalty through individual stock ownership. Journal of Product \& Brand Management, 13(7), 488-49.

Shum, M. (2004). Does Advertising Overcome Brand Loyalty? Evidence from the Breakfast-Cereals Market. Journal of Economics \& Management Strategy, 13, 241.

Stanlay, J. B. \& Vincent, J. B. (1984), Social Perceptions and The By-Products Of Advertising, Journal Of Communication, Summer .

Story, J. \& Loroz, S. P. (2005). Technological congruence and perceived quality of brand extensions. Journal of Product and Brand Management, 14(7), 438-44.

Tong, X. (2006). Creation of brand equity in the Chinese clothing market. A Dissertation Presented to the Faculty of the Graduate School University of Missouri-Columbia.

Uncles, M. \& Dowling, G. (1998). Consumer Loyalty Marketing in Repeat-purchase Markets, University of New South Wales, Sydney, Australia, .

Wilcox, B. W., Laverie, A. D., Kolyesnikova, N., Duhan, F. D. \& Dodd, H. T. (2008). Facets of brand equity and brand survival: A longitudinal examination. International Journal of Wine Business Research, 20(3), 202-214.

Yasin, M. N., Noor, N. M. \& Mohamad, O. (2007). Does image of country-of-origin matter to brand equity? Journal of Product \& Brand Management, 16(1) 38-48.

Yoo, B. \& Donthu, N. (2001). Developing and validating a multidimensional consumer-based brand equity scale. Journal of Business Research, 52, 1-14.

Yoo, B., Donthu, N. \& Lee, S. (2000). An examination of selected marketing mix elements and brand equity. Journal of the Academy of Marketing Science, 28(2), 195-211.

Zeithaml, V. A. (1988). Consumer perceptions of price, quality, and value: a means-end model and synthesis of evidence. Journal of Marketing, 52, 2-2. 